\title{
TERRITORIALIDADES URBANAS: A REPRESENTAÇÃO SIMBÓLICA DA CIDADE ANDINA NA LITERATURA PERUANA
}

\author{
Flávio Reginaldo Pimentel ${ }^{1}$ \\ Márcia Aparecida da Silva Pimentel ${ }^{2}$
}

\begin{abstract}
RESUMO
Este artigo tem como objetivo discutir as diversas territorialidades urbanas geradas a partir da representação simbólica da cidade de Cusco, localizada na Cordilheira dos Andes. Tem como foco principal a visão do narrador-personagem do romance Os rios profundos (1958), do escritor peruano José María Arguedas. Ernesto é um adolescente que chega a Cusco, em companhia de seu pai, e passa por um processo de múltiplos devires que o deslocam de sua territorialidade. A tradição e a modernidade, presentes nesse espaço urbano, fazem com que ele reflexione sobre o papel que a cidade cumpre na construção das múltiplas identidades geradas a partir de tal imbricamento. Ernesto vive conflitos, contradições e devaneios, que a todo momento o confrontam com a realidade a que está subordinada a população indígena na cidade. Há um processo de heterogeneidade e hibridismo cultural na narrativa, fazendo com que Ernesto fique constantemente dividido em um terreno movediço. Há uma interfase entre a literatura e a filosofia que acrescenta novos olhares aos estudos literários, a partir do conceito de território e territorialidades. A perspectiva teórica adotada é a de territorialização-desterritorialização-reterritorialização, definidas por Gilles Deleuze e Félix Guattari (1997). Tais conceitos aparecem nos escritos destes autores, em $O$ Anti-Édipo (1972), e desdobrados, sobretudo, em Mil Platôs (1980) e $O$ que é a filosofia? (1991).
\end{abstract}

Palavras-chave: Territórios. Territorialidades. Literatura. Cusco.

\section{RESUMEN}

Este artículo tiene como objetivo discutir las distintas territorialidades urbanas generadas a partir de la representación simbólica de la ciudad del Cusco, ubicada en la Cordillera de los Andes. Su eje principal es la visión del personaje narrador de la novela Los ríos profundos (1958), del escritor peruano José María Arguedas. Ernesto es un adolescente que llega al Cusco, en compañía de su padre, y atraviesa un proceso de devenir múltiple, que lo desplaza de su territorialidad. La tradición y modernidad, presentes en este espacio urbano, le hace reflexionar sobre el papel que juega la ciudad en la construcción de las múltiples identidades generadas a partir de tal superposición. Ernesto vive conflictos, contradicciones y ensueños, que constantemente lo confrontan con la realidad a la que está subordinada la población indígena de la ciudad. Hay un proceso de heterogeneidad e hibridación cultural en la narrativa, que hace que Ernesto esté constantemente dividido en un terreno cambiante. Existe una interrelación entre literatura y filosofía, que aporta nuevas perspectivas a los estudios literarios, partiendo del concepto de territorio y territorialidades. La perspectiva teórica adoptada es la de territorialización-desterritorialización-reterritorialización, definida por Gilles Deleuze y Félix Guattari (1997). Tales conceptos aparecen en los escritos de

\footnotetext{
${ }^{1}$ Professor do Instituto Federal do Pará campus Belém. Graduação em Letras pela Universidade Federal do Mato Grosso do Sul/UFMS. Mestrado em Letras pela Universidade Federal do Pará/UFPA. Doutorando em Literatura e Crítica Literária pela Pontifícia Universidade Católica de São Paulo (PUC/SP). Bolsista CAPES/PROSUC. E-mail: flaviorpimente12014@gmail.com.

2 Doutorado em Geografia (Geografia Física) pela Universidade de São Paulo. É professora efetiva da Universidade Federal do Pará/UFPA. Integra os Programas de Pós-Graduação de Geografia (PPGeo), de Ciências Ambientais (PPGCA) e de Gestão de Riscos e Desastres (PPGGRD- profissional). Coordenadora do Grupo de Estudo Paisagem e Planejamento Ambiental - GEPPAM/UFPA. E-mail: marciapimentel1989@gmail.com
} 
estos autores, en $O$ Anti-Édipo (1972), y se desarrollan, sobre todo, en Mil Platôs (1980) y $O$ que é a filosofía? (1991).

Palabras clave: Territorios. Territorialidades. Literatura. Cusco.

Data de submissão: 25.08 .2020

Data de aprovação: 20.10 .2020

\section{INTRODUÇÃO}

A cidade de Cusco, está localizada no Valle de Huatanay, ou Vale Sagrado dos Incas, na Cordilheira dos Andes. Está, aproximadamente, 3.400 metros acima do nível do mar. Administrativamente, o Peru é dividido em 25 regiões. A região de Cusco e a província de Cusco recebem o mesmo nome, pois é onde está localizada a antiga capital do império Inca.

De acordo com antigas lendas ${ }^{3}$, a localização da cidade se deve ao fato dos filhos do deus Sol, ou Inti, Manco Capac e Mama Ocllo, a serviço de seu pai, ensinarem aos homens onde deveriam se organizar como uma sociedade desenvolvida, pois estes viviam de forma selvagem pelo mundo. Os filhos do deus Sol empreendem uma jornada e encontram, nesta região, o lugar ideal para construir a cidade sagrada. Era ali que deviam viver os filhos do deus, os imperadores e povo, também chamados de Incas. Desta forma, Cusco se torna a capital de Tahuantinsuyu, ou império Inca.

O presente trabalho tem como objetivo discutir as diversas territorialidades urbanas geradas a partir da representação simbólica e cultural da cidade de Cusco. Tem como corpus o romance $O$ s rios profundos (1958), do escritor peruano José María Arguedas. No romance, o narrador-personagem é Ernesto, um adolescente que chega na cidade em companhia do pai e passa por um processo de múltiplos devires que o deslocam de sua territorialidade.

A produção artística de Arguedas está localizada na primeira metade do século XX, em pleno desenvolvimento da modernidade. Momento em que há uma enorme profusão de conceitos, fatos históricos, muitas manifestações artísticas e literárias. Um verdadeiro "turbilhão" de eventos culturais, "[...] ela [a modernidade] nos despeja a todos num turbilhão de permanente desintegração e mudança, de luta e contradição, de ambiguidade e angústia. Ser moderno é fazer parte de um universo no qual, como disse Marx, "tudo que é sólido desmancha no ar" (BERMAN, 2007, p. 24).

A partir da representação da cidade de Cusco, busca-se adentrar na narrativa arguediana com o intuito de explorar a riqueza literária; artística; simbólica; e cultural do referido espaço urbano. A imagem produzida a partir da percepção do narradorpersonagem dá a dimensão do valor simbólico que a cidade representa no mundo andino e que se destaca no primeiro capítulo da obra literária.

Sabe-se que a modernidade, ou modernismo, enquanto momento histórico; artístico; e cultural, é um período que não é fácil de estabelecer com exatidão. Aponta-se como iniciado por volta do ano 1880, seguindo até meados dos anos de 1950 (MOISÉS,

\footnotetext{
${ }^{3}$ Uma das mais tradicionais lendas é a que o Deus Sol mandou à terra seu filho e sua filha para que doutrinassem e ensinassem aos homens a cultivar a terra, criar animais, viver em casas e povoados e lhes predicassem leis, para que soubessem viver como homens racionais e não como bestas. Assim, o Deus Sol colocou seus filhos no lago Titicaca. [...] Depois de reunir o povo que vivia nas redondezas a serviço do Deus Sol, deveriam mantê-los em ordem e justiça e tratá-los sempre com piedade. Os filhos do Sol assim fizeram e no local onde a vara de ouro afundou, criaram Cuzco (Garcilaso de la Vega, 1976, vol. I, cap. XV), cidade que se tornaria a capital do Tahuantinsuyu, que, conforme Gonzalez Holguín (1989, p. 336), foi o nome dado às quatro regiões que formavam o território inca: Antisuyu, Colassuyu, Contisuyu e Chinchasuyu (PORTUGAL, 2010, p. 114).
} 
2001). De qualquer forma, considerando a modernidade como experiência de tempo e espaço, ela é a experiência que foi compartilhada por homens e mulheres em várias partes do mundo (BERMAN, 2007), inclusive na Cordilheira dos Andes.

A tradição e a modernidade, presentes no espaço urbano de Cusco, faz com que Ernesto reflexione sobre o papel que a cidade cumpre na construção das múltiplas identidades geradas a partir de tal relação. Ernesto vive conflitos, contradições e devaneios, que, a todo momento, o confrontam com a realidade a que está subordinada a população indígena na cidade. Há um processo de heterogeneidade e hibridismo cultural na narrativa, fazendo com que Ernesto fique constantemente dividido em um terreno movediço.

Busca-se, nesse sentido, estabelecer uma interfase entre a literatura e a filosofia, que acrescenta novos olhares aos estudos literários, a partir do conceito de território e territorialidade. Usando uma metodologia teórico-reflexiva de caráter qualitativo, com leituras e levantamento bibliográfico sobre o tema, entende-se os processos de territorialização-desterritorialização-reterritorialização, definidas por Gilles Deleuze e Félix Guattari (1997), como suporte teórico para adentrar ao texto literário. Tais conceitos aparecem nos escritos desses autores, em O Anti-Édipo (1972), e desdobrados, sobretudo, em Mil Platôs (1980) e O que é a filosofia? (1991).

\section{AS MÚLTIPLAS TERRITORIALIDADES: DIÁLOGOS ENTRE FILOSOFIA E LITERATURA}

O território, historicamente, foi entendido como uma área de domínio políticogeográfico, que servia para delimitar as fronteiras. As nações modernas tiveram a necessidade de criar uma espécie de entidade político/jurídica, as transformando em Estado, buscando uma soberania própria. Mas, esse conceito tradicional foi se modificando no decorrer do século XX. O território passa a ser entendido como um espaço produzido, que é apropriado e valorizado de acordo com os meios de produção capitalista, envolvendo muitas relações entre o Estado, empresas e as diversas classes sociais que ali existem. Logo, se estabelecem novas relações de poder dentro do território. Esta visão está vinculada, principalmente, pela questão econômica, política e social.

Já no final do século XX e início do XXI, o território ganha novas acepções e passa a ser entendido não somente pela sua materialidade, mas, também, pela imaterialidade das representações e percepções, sejam individuais ou coletivas. Lugares; símbolos; ícones; discursos; comportamentos, passam a fazer parte dessa nova construção conceitual de território, acrescenta-se o aspecto cultual a este entendimento.

Percebe-se uma nova apropriação dos conceitos de espaços, públicos e/ou privados, além dos espaços físicos/geográficos, destaca-se, também, os espaços discursivos. Em outras palavras, entende-se o processo de territorialização-desterritorializaçãoreterritorialização, como algo em movimento, múltiplo e diverso. Essas novas formas de pertencimento e domínio, dentro de um recorte espacial, são chamadas de territorialidades, que servem como referências à novas formas de pertencimento, o que indica, também, as identidades territoriais (HAESBAERT, 1999).

Sobre a questão das identidades territoriais, é prudente afirmar que existe certo consenso nas Ciências Humanas de que a identidade é uma construção social. A partir desta afirmação, os diversos grupos sociais criam significados, pois suas identidades estão vinculadas a determinada cultura; ideologia; religião; etnia; território, que são, aos poucos, construídas e vão se cristalizando. Neste sentido, a identidade é uma construção subjetiva, que pode ser individual ou coletiva, uma espécie de pertencimento territorial, dando a ideia de territorialidade (CHELOTTI, 2010). 
Em Mil Platôs (1997), Gilles Deleuze (1925-1995) e Félix Guattari (1930-1992), um filósofo e o outro psicanalista, apresentam o texto Acerca do Ritornelo, onde, a partir do símbolo musical ritornelo, elaboram novos conceitos e perspectivas de análise relacionados à definição de território. O ritornelo se relaciona com o espaço subjetivo e abstrato. Seria um agenciamento de territórios, como vemos:

\begin{abstract}
A noção de território aqui é entendida num sentido muito amplo, que ultrapassa o uso que fazem dele a etologia e a etnologia. Os seres existentes se organizam segundo territórios que os delimitam e os articulam aos outros existentes e aos fluxos cósmicos. O território pode ser relativo tanto a um espaço vivido, quanto a um sistema percebido no seio da qual um sujeito se sente "em casa". O território é sinônimo de apropriação, de subjetivação fechada sobre si mesma. Ele é o conjunto de projetos e representações nos quais vai desembocar, pragmaticamente, toda uma série de comportamentos, de investimentos, nos tempos e nos espaços sociais, culturais, estéticos, cognitivos. (GUATTARI; ROLNIK, 1986, p. 323, apud HAESBAERT; BRUCE, 2002, p. 6).
\end{abstract}

Os seres se organizam nos mais diversos territórios, que, por sua vez, vão interagir e inter-relacionar-se com outros territórios existentes. Neste sentido, os autores propõem que o território pode ser tanto relativo, no sentido de que pode ser um espaço físico vivido, quanto um sistema percebido ou sentido, onde o indivíduo se "sente em casa", um lugar de identificação (HAESBAERT; BRUCE, 2002). Há uma relação de proximidade, mas, ao mesmo tempo, de distanciamento, de fluxo contínuo de movimentos. Uma inter-relação de territórios e territorialidades.

O território é de fato um ato, que afeta os meios e os ritmos, que os "territorializa". O território é o produto de uma territorialização dos meios e dos ritmos. [...] Um território lança mão de todos os meios, pega um pedaço deles, agarra-os (embora permaneça frágil frente a intrusões). Ele é construído com aspectos ou porções de meios. Ele comporta em si mesmo um meio exterior, um meio interior, um intermediário, um anexado. Ele tem uma zona interior de domicílio ou de abrigo, uma zona exterior de domínio, limites ou membranas mais ou menos retrateis, zonas intermediárias ou até neutralizadas, reservas ou anexos energéticos [...] Precisamente, há território a partir do momento em que componentes de meios param de ser direcionais para se tornarem dimensionais, quando eles param de ser funcionais para se tornarem expressivos. Há território a partir do momento em que há expressividade do ritmo. É a emergência de matérias de expressão (qualidades) que vai definir o território. (DELEUZE; GUATTARI, 1997, p. 105).

De acordo com Deleuze e Guattari (1997), existe um movimento constante no interior do território, como a citação da criança no início do texto Acerca do Ritornelo (1997), ela anda e cantarola, na tentativa de superar o caos existente, superar o medo, que busca, a partir de uma zona interior de domicílio ou de abrigo, para proteger-se, para sentir-se em casa, segura do caos. São buscas constantes por territorialidades que são múltiplas e diversas. Tal movimento é resultado das muitas determinações territoriais a que o indivíduo está condicionado. Condicionamentos materiais e imateriais; contradições de caráter social; questões econômicas; políticas; e, sobretudo, culturais, fazem com que a "criança" salte ao mesmo tempo que canta. Em constante movimento.

Sublinhou-se muitas vezes o papel do ritornelo: ele é territorial, é um agenciamento territorial. O canto de pássaros: o pássaro que canta marca assim seu território... Os próprios modos gregos, os ritmos hindus são territoriais, provinciais, regionais. O ritornelo pode ganhar outras funções, amorosa, profissional ou social, litúrgica ou cósmica: ele sempre leva terra consigo, ele tem como concomitante 
uma terra, mesmo que espiritual, ele está em relação essencial com um Natal, um Nativo. (DELEUZE; GUATTARI, 1997, p. 102).

Um ritornelo é um constante movimento de entrada e saída do território. Um movimento que permite a saída do velho, onde é recriado um novo, um movimento de descontinuidade e continuidade. O velho permanece no novo, não é eliminado, mas retorna, sob outra forma, no novo. Uma espécie de abarcamento das totalidades anteriores, agora contidas no novo, nos novos ritornelos, nos novos territórios. Em constante deslocamento.

Este deslocamento seria, em outras palavras, a desterritorialização apontada por Deleuze e Guattari (1997). O processo de desterritorialização vai preceder o território e, ao mesmo tempo, ser, também, um processo de territorialização ou reterritorialização. Há, na verdade, vários processos territoriais que se inter-relacionam dentro de um mesmo território, processos estes de cunho político; social; cultural; simbólicos; entre outros. Isso culmina em novos processos, pois nenhum processo territorial pode ser analisado isoladamente. Pode-se definir como sendo várias territorialidades que se intercruzam em movimento, se atravessam, dentro de um mesmo território.

Nessa perspectiva, percebe-se que há uma abertura, um movimento em direção ao novo, um abandono do velho e um "lançar-se" ou "deslocar-se", como se vê abaixo:

Agora, enfim, entreabrimos o círculo, nós o abrimos, deixamos alguém entrar,
chamamos alguém, ou então nós mesmos vamos para fora, nos lançamos. Não
abrimos o círculo do lado onde vêm acumular-se as antigas forças do caos, mas
numa outra região, criada pelo próprio círculo. Como se o próprio círculo tendesse
a abrir-se para um futuro, em função das forças em obra que ele abriga. E dessa vez
é para ir ao encontro de forças do futuro, forças cósmicas. Lançamo-nos,
arriscamos uma improvisação. Mas improvisar é ir ao encontro do Mundo, ou
confundir-se com ele. Saímos de casa no fio de uma cançãozinha. Nas linhas
motoras, gestuais, sonoras que marcam o percurso costumeiro de uma criança,
enxertam-se ou se põem a germinar "linhas de errância", com volteios, nós
velocidades, movimentos, gestos e sonoridades diferentes. (DELEUZE;
GUATTARI, 1997, p. 100).

Há, na verdade, uma constante criação e recriação de territórios. Na perspectiva deleuzeguattariana, seria uma busca ou um "lançar-se" a um devir ou devires, abandonando antigos territórios, desterritorializando-se, através de linhas de fuga que surgem e que apontam para outras linhas e assim sucessivamente. A vivência experimentada a partir dessa aventura de fuga, de deslocamentos, de lançamento, traz novas experimentações surpreendentes.

Deleuze e Guattari (1992), chamam de processo de desterritorialização, pois, para eles, "a terra não cessa de operar um movimento de desterritorialização in loco pelo qual ultrapassa todo o território: ela é desterritorializante e desterritorializada" (DELEUZE; GUATTARI, 1992, p. 110). Como uma ação de desconstruir e reconstruir novamente. Neste sentido, é importante entender que a desterritorialização não é uma linha de chegada, mas ela faz parte de todo o processo de criação de novos territórios, ou mesmo do abandono dele. "A desterritorialização é o movimento pelo qual 'se' abandona o território" (DELEUZE; GUATTARI,1995, p. 238).

É importante salientar que esse "abandono de território" não é completo, ele não desaparece. Na verdade, ganha novos contornos, é alterado, ganha novos sentidos e significados. As linhas de fuga, por onde é possível desterritorializar-se, estarão sempre presentes, abertas, dispostas, num ritmo contínuo de movimentos múltiplos (GRANETTO MOREIRA; DAL MOLIN, 2019). Estas linhas de fuga possibilitam novas 
territorializações e reterritorialização, o que pode ser entendido como um processo rizomático.

Para que haja todo esse processo de desterritorialização e reterritorialização, a busca por novos territórios, é preciso perceber que os agenciamentos fluem e estão conectados, se desconectam e voltam a conectar-se novamente. Os agenciamentos ultrapassam os espaços físico-geográficos para a criação de territórios, podendo ser de dois tipos, os agenciamentos coletivos de enunciação; e os agenciamentos maquínicos de corpos (HAESBAERT; BRUCE, 2002).

Por agenciamentos maquínicos de corpos entende-se que seriam as máquinas sociais, as diversas relações existentes entre os diversos corpos, humanos e animais. Seria como uma grande mistura de corpos que se entrelaçam e se dispõe dentro de uma sociedade. Já os agenciamentos coletivos de enunciação referem-se à linguagem, aos elementos que compõe a língua e todas as suas variáveis, sejam elas signos e/ou símbolos, elementos que, de alguma maneira, transmitem expressões de significação.

\footnotetext{
Com esse movimento mútuo de agenciamentos, um território se constitui. Uma aula é um território porque para construí-la é necessário um agenciamento coletivo de enunciação e agenciamento maquínico de corpos; a mão cria um território na ferramenta; a boca cria um território no seio. O conceito de território de Deleuze e Guattari ganha essa amplitude porque ele diz respeito ao pensamento e ao desejo desejo entendido aqui como uma força criadora, produtiva. Deleuze e Guattari vão, assim, articular desejo e pensamento. Podemos nos territorializar em qualquer coisa, desde que façamos agenciamento maquínico de corpos e agenciamentos coletivos de enunciação. O território pode ser construído em um livro a partir do agenciamento maquínico das técnicas, dos corpos da natureza (as árvores), do corpo do autor e das multiplicidades que o atravessam; e do agenciamento coletivo de enunciação, nesse caso, um sistema sintático e semântico. (HAESBAERT; BRUCE, 2002, p. 7).
}

Na perspectiva deleuzeguattariana, criar e recriar territorialidades é uma aventura. É percorrer caminhos diversos, múltiplos, que se cruzam e entrelaçam, seguindo novos percursos, como na raiz rizoma. Neste sentido, buscar linhas de fuga é buscar novas possibilidades para novos devires, também cheios de novos territórios, sempre em constante movimento. São possibilidades criativas, possibilidades de sair do espaço sedentário e construir devires outros.

A partir desse entendimento é que se desenvolve a proposta inicial deste trabalho, sobre as territorialidades do espaço urbano na literatura, em especial na narrativa ficcional arguediana de $O s$ rios profundos. Como está representada, simbolicamente, a cidade de Cusco para o narrador-personagem? Como ele a vê e a percebe? Qual a relação estabelecida na construção de novos territórios? Como estão articuladas as diversas territorialidades no texto de José María Arguedas?

Não há intenção de fazer análises fechadas e "verdadeiras", mas apresentar propostas de possíveis leituras e análises de uma narrativa ficcional, estabelecendo um diálogo entre a literatura e filosofia. O que só enriquece os estudos literários, utilizando-se de conceitos de outras áreas das Ciências Humanas e Sociais.

\section{A REPRESENTAÇÃO DOS ESPAÇOS URBANOS NA LITERATURA}

Há uma interessante representação da cidade e sua presença na literatura. Muitos escritores utilizam a cidade como espaço literário para desenvolver suas narrativas ficcionais. Como exemplos temos Combray, Macondo e Yoknapatawpha, dos escritores Marcel Proust, Gabriel García Márquez e William Faulkner, respectivamente. Eles 
utilizam a originalidade para criar suas próprias cidades e/ou espaços urbanos, como forma de enriquecer a tessitura literária. Mesmo que possam ser identificadas com "cidades verdadeiras e legítimas", por onde tais escritores viveram, não se pode mais negar que, ao serem incluídas no texto literário, tais espaços urbanos se tornam espaços ficcionais.

Não somente em romances ou contos, mas na poesia e/ou crônicas, a presença da cidade é marcante, como vemos:

\begin{abstract}
Basta pensarmos na Paris de Baudelaire ou de Zola, na Londres de Dickens, na Petersburgo de Dostoievski, na São Paulo de Mário de Andrade ou Alcântara Machado, na Buenos Aires de Borges ou Roberto Arlt. Autores, entre tantos outros, que expressaram a sensibilidade moderna vinculada ao ambiente urbano, formulando imagens e oferecendo experiências formais que permitem ainda hoje nos aproximarmos daquelas cidades. (CASTRO, 2016, p. 99).
\end{abstract}

Dessa forma, o papel da cidade é alterado. Acrescenta-se um novo olhar sobre ela. Um olhar mais detalhado, carregado de subjetividade e sentimentos, a partir da percepção e da experiência. Esse novo olhar traz novas representações e referenciais epistêmicos nessa relação com a literatura.

\begin{abstract}
Já se disse uma vez que "sempre existiu uma íntima ligação entre a literatura e as cidades", pois é nas cidades que se encontram "as instituições literárias básicas: editoras, patronos, bibliotecas, museus, livrarias, teatros, revistas". É também no espaço urbano que "as pressões, as novidades, os debates, o lazer, o dinheiro, a alta rotatividade das pessoas, os fluxos dos visitantes, o som de muitas línguas, a rápida troca de ideias e estilos, a oportunidade de especialização artística" se realizam. (CASTRO, 2016, p. 99).
\end{abstract}

É no espaço da urbe que a circulação literária moderna gera novas representações, principalmente no final do século XIX e século XX. Com o advento da modernidade, o escritor/artista se vê obrigado a percorrer, como um flâneur, os mais diversos ambientes proporcionados pela cidade. Desta forma, gera uma reflexão de como utilizar a cidade como estratégia na construção da narrativa literária, entendendo-a como espaço que gera representação simbólica e cultural, mesmo que de forma fragmentada, mas que coexistem nos múltiplos territórios imbricados na cidade moderna.

A pólis produz diversos discursos, análises e distopias pelo seu caráter heterogêneo, fraturado e incompleto. Esse caráter origina, ao escritor/artista da modernidade, significações e ressignificações, o que, consequentemente, estará presente no discurso literário do narrador e/ou personagens, e que pode confundir a realidade e a ficção. De qualquer forma, não se pode negar que esse espaço se torna, de alguma maneira, um referencial da realidade, pois mantêm uma estreita relação. É uma nova versão da realidade subjetiva do autor transcrita na forma de narrativa literária. A cidade é um lugar constituído por muitas identidades, o que, consequentemente, produz e irradia cultura, imaginação e fantasia.

Não poderia ser diferente na literatura chamada latino-americana, em especial a literatura peruana. Entre os escritores mais emblemáticos do Peru, encontra-se José María Arguedas (1911-1969). Na obra Os rios profundos, a cidade de Cusco aparece no primeiro capítulo. A cidade que nasceu para ser uma "cidade sagrada", mas que, com a invasão branca europeia no século XVI, aos poucos vai perdendo sua aura.

Escritores como Tzvetan Todorov, em A conquista da América: a questão do outro, Antonio Cornejo Polar, em Escribir en el aire, Bernard Vincent, em 1492 Descoberta ou invasão?, Ángel Rama, em Transculturación narrativa em América Latina, entre muitos outros pensadores sobre o processo de conquista e colonização 
da América, definem esse momento da conquista como sendo o dos primeiros contatos entre os povos aqui encontrados. Logo após esse primeiro momento chamado de conquista - e para efetivar seu domínio sobre os povos "vencidos", os europeus darão início ao processo de colonização, cuja estrutura se apresenta dividida em dois pólos: o do colonizador, que será sempre hegemônico, "superior"; e o do colonizado, sempre "inferior" e "explorado". (KAUSS; LIMA, 2014, p. 156).

Com o advento da modernidade e os diversos processos de migração e movimentos de pessoas no interior do Peru, a cidade passa por um convívio de diversas culturas, muitas delas completamente antagônicas uma das outras. Surgem novas representações que, aos poucos, modelam a cidade. "As pedras que, hoje, dão lugar ao templo católico - a Igreja do Senhor de los Temblores - foram as mesmas que davam forma ao Coricancha - o templo ao deus Sol dos Incas. Isso se repete em quase todas as construções da cidade histórica: a sobreposição de uma cultura sobre a outra" (KAUSS; LIMA, 2014, p. 155).

Essa forma de relação persiste até os dias de hoje, onde a cultura ocidental tenta, de diversas maneiras, apagar ou silenciar as antigas formas de representação simbólica que Cusco é para os descendentes dos Incas. Muitas construções, muros e casas tem na sua base as pedras que foram trabalhadas pelos indígenas, mas, por cima, paredes de construções modernas, feitas pelos espanhóis, dão opulência e tentam enterrar a representação de uma cultura. Na tentativa de trazer a modernidade a lugares distantes e autóctones, essas transformações de caráter físico assentam sua disposição em combater qualquer resquício simbólico existente.

O que pode muitas vezes cair em ciladas, pois, no caso da literatura, é possível adentrar no imaginário cultural do mundo andino através do discurso narrativo do autor/artista. Arguedas, como nenhum outro escritor peruano, soube representar essa voz. A cidade arguediana de Cusco é o espaço, o locus, das muitas percepções da cultura nativa.

Arguedas faz uma reflexão, que procura estender a seus leitores, sobre a solidez
das raízes ancestrais da cultura andina, que são matrizes da identidade nacional
peruana, comparando-as com os valores impostos pela cultura ocidental, pela
violência da dominação, pela atitude de dependência frente às metrópoles
estrangeiras, pelo desprezo e pela marginalização das raízes autóctones. (KAUSS;
LIMA, 2014, p. 158).

A cidade passa a ser multifacetada, pois adquire ambientes claros de duas culturas, a cultura branca europeia e a cultura nativa indígena. Além disso, Arguedas procura desmistificar o que por muitos anos no Peru foi latente, a cultura dos "da serra" com a cultura dos "da costa". Para Arguedas, a cultura andina e seus elementos representativos e simbólicos são o cerne que alimenta a cultura nacional, que muitas vezes é negada ou silenciada. Ele propõe uma síntese de um país mestiço, com traços de hibridação cultural e heterogeneidade (CORNEJO POLAR, 1994).

É a partir do encontro e da mescla de culturas que a narrativa arguediana ganha contornos sólidos e desmascara uma realidade. Mas a grandeza do texto literário não pode de forma nenhuma ser apagado, e Arguedas consegue dar uma poeticidade e literariedade a sua escritura. Cusco ganha a dimensão de ser um espaço de contrastes e efervescência, algo típico das cidades modernas. Ali se imbricam elementos do local e do global. Elementos de diversas culturas e linguagens.

[...] nos edifícios de Cuzco que se apresentam como símbolos perfeitos dessa mestiçagem: suas bases continuam sendo os muros de pedras perfeitamente cortadas e encaixadas sem o uso de nenhuma argamassa feitos pelos incas, enquanto a parte superior apresenta as construções feitas pelos europeus, no 
primeiro momento, e pelos mestiços depois. Os últimos, filhos da mistura das culturas ali encontradas, criativamente, assimilavam as lições da arte europeia ao mesmo tempo em que se colocavam abertos para receber as sugestões da arte andina. (KAUSS; LIMA, 2014, p. 158-159).

É nesse processo de construção simbólica que a cidade de Cusco é, para Arguedas, e, consequentemente, para seus personagens, a perfeita simbiose cultural da tradição e da modernidade, sobrepostas no mesmo espaço físico/geográfico. Partindo desta perspectiva, e utilizando o conceito de território e territorialidade, proposto por Deleuze/Guattari (1997), que se analisa a obra de José María Arguedas, na tentativa de dialogar e de estabelecer conexões entre a literatura e a filosofia, enriquecendo os estudos literários no continente.

\section{CUSCO EM OS RIOS PROFUNDOS: AS MÚLTIPLAS TERRITORIALIDADES}

O romance Os Rios Profundos, do escritor peruano José María Arguedas, foi publicado em 1958 pela primeira vez. O corpus utilizado neste artigo é a publicação feita pela Companhia das Letras em 2005 e traduzida para o português pela professora Josely Vianna Batista. Arguedas nasceu em 1911, em Andahuaylas, cidade situada na Cordilheira dos Andes. Ele foi etnólogo; folclorista; professor; ensaísta; e, principalmente, romancista. Logo nos primeiros anos de vida, uma experiência traçaria toda a sua trajetória literária e política, a convivência com os indígenas. Muito pequeno foi morar em um ayllu ${ }^{4}$.

Arguedas fez muitas viagens com o pai, percorrendo povoados e cidades na Cordilheira peruana. Foi mandado a viver junto aos índios, em uma fazenda, pela sua madrasta; isso proporcionou a Arguedas o aprendizado da língua quéchua, assim como o conhecimento da cultura e tradição daquele povo. Tal fato marca profundamente a vida do escritor. Ele cria uma empatia, amor e identidade para com os indígenas que o "desloca", a todo momento, em direção a muitos territórios que o atravessam constantemente.

Considerado como um dos escritores mais proeminentes da literatura peruana, é, também, um dos representantes da nova corrente indigenista, ou neo-indigenismo ${ }^{5}$, na América Latina no século XX. De forma peculiar, conseguiu reunir no texto literário elementos que podem ser identificados em sua obra, como: luta dos indígenas contra a exploração branca; mestiçagem; língua quéchua versus língua do colonizador (castelhano); territórios; história; cultura popular; identidade cultural; memória; entre outros temas.

Arguedas parece consciente de que, através do texto literário, deveria mostrar a realidade que viviam os povos indígenas no Peru. A colonização espanhola, e a constante exploração dos índios, fez brotar algo novo, uma cultura mesclada, híbrida, mestiça, cheia de heranças das duas culturas formadoras. Arguedas afirma claramente:

Eu não sou um aculturado; eu sou um peruano que orgulhosamente, como um demônio feliz, fala em cristão e em índio, em espanhol e em quéchua. Desejava converter essa realidade em linguagem artística e tal parece, segundo certo consenso, mais ou menos geral, que tenho conseguido. ${ }^{6}$

\footnotetext{
${ }^{4}$ Comunidades de índios. A base da produção agrícola dos incas era o ayllu, uma comunidade formada por pessoas que acreditavam na descendência única, ou seja, cada ayllu era reconhecida como uma grande família.

${ }^{5}$ A noção de neo-indigenismo no Peru foi apresentada por Tomás Escajadillo em sua tese de doutoramento, na Universidade Mayor de São Marcos, em que busca diferenciar o indigenismo "ortodoxo" do neo-indigenismo surgido no Peru a partir da obra de José María Arguedas.

${ }^{6}$ Trecho do discurso de José María Arguedas proferido ao receber o prêmio de Inca Garcilaso de La Vega, 1968. Disponível em: http://www.leeporgusto.com/cincuenta-anos-del-discurso-no-soy-un-aculturado-de-jose-mariaarguedas/. Tradução nossa.
} 
Há um entrecruzar de identidades e culturas que dialogam, e que Arguedas evidencia no texto literário. O livro Os rios profundos (2005), é um romance que abre a primeira janela para olhar a situação do povo indígena no Peru daqueles anos. Nele, encontramos Ernesto, narrador-personagem, que, adulto, puxa pela memória os acontecimentos distantes. No primeiro capítulo, que tem o título $O$ velho, (Arguedas, 2005, p. 7), aparecem, Ernesto, o pai e o Velho, tio do seu pai. O velho é um personagem avarento, um homem rico que possui muitas propriedades e serviçais. Inicia-se com a entrada simbólica de Ernesto e do pai na cidade sagrada de Cusco, capital do antigo império Inca. Por isso, guarda singularidades que fazem com que os personagens passem por momentos de profunda reflexão, deslocamentos e devires incertos.

A cidade de Cusco é a perfeita representação dos diversos territórios que se entrecruzam. É na cidade que encontramos a representação da igreja; do Estado; das culturas ameríndias; e da cultura europeia, todas ali, chocando-se e estabelecendo relações diversas e múltiplas.

Era noite quando entramos em Cusco. Fiquei surpreso com a estação de trem e a avenida larga pela qual, lentamente, avançávamos. A luz elétrica era mais fraca que a de alguns lugarejos que eu conhecia. Grades de madeira ou de aço defendiam jardins e casas modernas. A Cusco de meu pai, aquela que ele me descrevera umas mil vezes, não podia ser essa. (ARGUEDAS, 2005, p. 8).

No trecho acima, Ernesto não reconhece a Cusco descrita anteriormente pelo seu pai. Existe certa desconfiança, um estranhamento que o desconforta. A cidade era bem maior que imaginava, pois possuía elementos da modernidade e marcas territoriais ainda não vistas por ele, diferentes das que ele tinha presenciado em outros lugares. Para Ernesto, que vive suas contradições, ele esperava encontrar elementos relacionados com a cultura incaica, pelo fato da cidade ter sido capital dos Incas. "Apareceram os balcões entalhados, as fachadas imponentes e harmoniosas, a perspectiva das ruas ondulantes na encosta da montanha. Mas nem um muro antigo!" (ARGUEDAS, 2005, p. 8).

Era como se Cusco, que significa, em quéchua, "umbigo" ou "centro do mundo", devesse ter mantido os traços originais da cultura nativa, ter mantido em seus espaços somente elementos culturais indígenas, mas não é isso que ele constata. "Esses balcões salientes, as fachadas de pedra e os saguões entalhados, os grandes pátios com arcos, eu já conhecia. Vira-os sob o sol de Huamanga. Eu esquadrinhava as ruas procurando muros incas" (ARGUEDAS, 2005, p. 8).

Percebe-se que Ernesto busca ancorar sua territorialidade nos traços da cultura inca, pois ele vivia em dois mundos, um mundo mestiço, híbrido e heterogêneo, composto pela cultura ocidental e pela cultura indígena. Era filho de brancos, mas que aprendeu a falar e a respeitar a língua e a cultura indígena. "Eu tinha catorze anos; [...] depois que meu pai me resgatou e comecei a vagar com ele pelos povoados, vi que em toda parte as pessoas sofriam. A "María Angola"7 talvez chorasse por todos eles, lá em Cusco" (ARGUEDAS, 2005, p. 23).

Ernesto cria uma enorme empatia pelos $\operatorname{pongos}^{8}$, que são índios que serviam aos patrões em suas fazendas. Há, com isso, um movimento de disputa de território, pois ele se vê dividido entre os dois mundos, entre dois territórios. O personagem reconstrói, a todo momento, suas territorialidades, na perspectiva apontada por Deleuze e Guattari (1997), em que o território é sinônimo de apropriação e subjetivação, uma busca por linhas de fuga, que o sujeito percorre para construir e reconstruir seu próprio território, sua própria territorialidade.

\footnotetext{
${ }^{7}$ Nome dado ao sino da catedral de Cusco.

${ }^{8}$ Serviçais que trabalhavam nas fazendas dos ricos proprietários de terra e não possuíam salários.
} 


\begin{abstract}
- Olhe ali adiante! - disse meu pai. - Foi o palácio de um inca.
Quando meu pai apontou para o muro, eu parei. Era escuro, áspero; atraia com sua face recostada. A parede branca do primeiro andar começava em linha reta sobre o muro.

- Você vai poder vê-lo com calma, mais tarde. Vamos atrás do Velho - disse-me. (ARGUEDAS, 2005, p. 8).
\end{abstract}

A tentativa de sobrepor uma cultura sobre a outra é marcante nas construções de muitas cidades andinas, em particular em Cusco. Como vemos no excerto, onde Ernesto rapidamente percebe que o muro incaico é usado como base, mas suas paredes estão "perfeitamente cortadas e encaixadas sem o uso de nenhuma argamassa feitos pelos incas, enquanto a parte superior apresenta as construções feitas pelos europeus, no primeiro momento, e pelos mestiços depois" (KAUSS; LIMA, 2014, p. 158-159).

Quando Ernesto percebe as contradições, as incertezas e as situações de exploração das relações de poder existentes no espaço urbano, ele sai em busca de "linhas de fuga". Se desloca pelas ruas e praças em busca de elementos que seriam aglutinadores de antigos territórios, desfeitos pela presença da colonização espanhola "Corri para ver o muro" (ARGUEDAS, 2005, p. 11). O muro incaico representa o que há de mais belo e perfeito nas construções da cidade. Neste sentido, o muro é o elemento aglutinador de identidade, orgulho da cultura nativa indígena para os cusquenhos e seus descendentes.

Formava uma esquina. Avançava ao longo de uma rua larga e continuava em outra estreita e mais escura, com fedor de urina. Essa rua estreita escalava a encosta. Caminhei diante do muro, pedra após pedra. Afastava-me alguns passos, contemplava-os e voltava a me aproximar. Toquei as pedras com as mãos; segui a linha ondulante, imprevisível, como a dos rios, em que se juntam os blocos de rocha. Na rua escura, no silêncio, o muro parecia vivo, sobre a palma de minhas mãos flamejava a juntura das pedras que eu tocara. (ARGUEDAS, 2005, p. 11).

Percebe-se a importância e a representação do muro inca. É por ele que o narradorpersonagem encontra diálogo consigo e com sua ancestralidade. Há uma comparação das linhas do muro com os rios. A presença dos rios na obra de Arguedas é significativa, para o autor, os rios são como pontes, "pachachaca! ponte sobre o mundo, significa este nome" (ARGUEDAS, 2005. p. 62). No decorrer do romance Os rios profundos, os rios, vales e montanhas vão representar a relação profunda com a natureza andina, com significações que vão além de descrições; representam a cultura e a identidade dos povos originários.

$\mathrm{O}$ muro inca representa a territorialidade perdida com a qual Ernesto procura estabelecer uma linha de encontro quando está frente a ele. Esta territorialidade perdida, na verdade está ali, pulsando forte, como propõe Deleuze e Guattari (1997) ao falar que os antigos territórios não deixam de existir, mas permanecem recriados, agora em novos territórios, como no caso dos muros e construções espalhadas pela cidade de Cusco, que são as representações simbólicas de identidades culturais perdidas, ou seja, as reterritorializações.

Há uma identidade territorial simbólica que se relaciona com o pertencimento daquele lugar, da serra, da Cordilheira. "Meu pai me falara de sua cidade natal, dos palácios e templos, e das praças, durante as viagens que fizemos, cruzando o Peru dos Andes, de leste a oeste e de sul a norte. Eu crescera nessas viagens" (ARGUEDAS, 2005, p. 12). Mais adiante temos:

Eram maiores, e mais estranhas do que eu imaginava, as pedras do muro inca; borbulhavam sobre o primeiro andar caiado, que, pelo lado da rua estreita, era cego. Lembrei-me então das canções quéchuas que repetem constantemente uma 
frase patética: yawar mauy, rio de sangue; yawar unu, água sangrenta; puk-tik', yawar k'ocha, lago de sangue que ferve; yawar wek'e, lágrimas de sangue. Não seria possível dizer yawar rumi, pedra de sangue, ou puk'tik', yawar rumi, pedra de sangue fervente? Era estático o muro, mas suas linhas todas fervilhavam e a superfície era cambiante, como a dos rios no verão, que têm um cimo assim, no centro caudal, que é a zona temível, a mais poderosa. Os índios chamam de yawar mayu esses rios turvos, porque exibem, sob o sol, um brilho em movimento, semelhante ao do sangue. Também chamam de yawar mayu o tempo violento das danças guerreiras, o momento em que os dançarinos lutam.

- Puk'tik, yawar rumi! - exclamei diante do muro, em voz alta. (ARGUEDAS, 2005, p. 12).

Percebe-se a riqueza da cosmovisão da cultura incaica no parágrafo acima. As associações feitas por Ernesto estão repletas de sentido semântico, que remetem ao mundo plural e heterogêneo no qual está inserido. Encontramos o rio; a água; o lago; a lágrima, todos elementos líquidos que apontam para uma fluidez, um movimento em diversas direções. Assim como o sangue, que é líquido e que dá vigor, dá vida. Nesse excerto, reforça-se as afirmativas anteriores sobre territorialidades, construções identitárias, deslocamentos. Nota-se, também, que José María Arguedas prefere manter expressões e palavras na língua quéchua, pois sabe que estão repletas de significações, e, portanto, fazer simples traduções não daria conta do simbólico que estas palavras representam.

Em outro trecho, encontramos Ernesto completamente em êxtase, passando por um processo de compreensão, de "purificação" e de entendimento:

- Papai - disse-lhe. - Cada pedra fala. Vamos esperar um pouquinho.

- Não vamos ouvir nada. Pois não é que elas falem. Você é que está confuso. Elas se mudam para sua mente e dali o inquietam.

- Cada pedra é diferente. Não estão cortadas. Estão se mexendo.

Pegou-me pelo braço.

- Parece que estão se mexendo porque são desiguais, mais do que as pedras dos campos. É que os incas transformavam a pedra em barro. Já lhe disse isso muitas vezes.

- Papai, parece que estão andando, se revirando, e estão quietas.

- Aonde quer que eu vá, as pedras que o Inca Roca mandou formar me acompanharão. Gostaria de fazer, aqui, um juramento. (ARGUEDAS, 2005, p. 14).

Vários pontos podem ser analisados neste trecho. Imaginário; identidade; deslocamentos; memória. Para Ernesto, as pedras do muro inca falam, transmitem mensagens que podem ser confusas, mas existe uma comunicação. Simbolicamente, é como se assumissem um papel aglutinador de resistência. É interessante analisar sobre o ponto de vista de disputa de territorialidades, pois, sobre o muro inca, são erguidas as paredes e construções espanholas. É uma relação de disputa, de luta, pois é como se o muro ficasse opaco, destacando-se mais a cultura do europeu branco.

Contrariando tudo isso, o personagem afirma, "Aonde quer que eu vá, as pedras que o Inca Roca mandou formar me acompanharão. Gostaria de fazer, aqui, um juramento" (ARGUEDAS, 2005, p.14). Ora, para Ernesto, é uma afirmação categórica de sua identidade cultural, mesmo sendo múltipla, heterogênea. Porque, na verdade, ele não tem intenção de que uma identidade se sobressaia a outra, mas que convivam nas suas multiplicidades, nas diferentes territorialidades construídas. Chama atenção no romance a construção de uma identidade, ou identidades, de Ernesto, que parecem situar-se num terreno tenso e conflitivo, por causa de sua imersão num universo cultural heterogêneo e dual. Constantemente ele é atravessado por situações que o fazem refletir e sensibilizar-se com o outro. Ernesto é atravessado por situações de deslocamento. 
Outra representação simbólica presente nessa chegada a Cusco é a catedral e seu sino. "Ao dominarem Cuzco, os espanhóis construíram a catedral no mesmo lugar em que estava o templo do deus Sol e um convento para freiras da ordem de Santa Catarina [...] foi levantado onde ficava o templo das Acllas" (KAUSS; LIMA, 2014, p. 161). As acllas eram sacerdotisas que serviam diretamente ao imperador Inca.

Sobre o sino da catedral de Cusco, ele estabelece uma marcação temporal e, também, traz tristeza e angústia para Ernesto. É como se a sonoridade, o bater do sino, o atravessasse, o deslocasse de seu território seguro de menino branco e o jogasse para fora, num movimento brusco, mas, ao mesmo tempo, despertador o levando à percepção de uma outra realidade, a realidade dura e verdadeira a que está condicionada a população pobre e indígena que mora na Cordilheira, e isso o entristece.

Enquanto caminhavam pelas ruas para que Ernesto conhecesse um pouco de Cuzco, pai e filho pararam ao ouvir o maior sino da Catedral chamado de Maria Angola. Esse sino foi instalado na torre no ano de 1659 e desde então o povo o cerca de lendas: seu canto mágico transforma tudo em ouro.... No texto, o badalar do sino parece ter o poder de tornar, por alguns momentos, novamente sagrada a cidade de Cuzco. (KAUSS; LIMA, 2014, p. 161).

Relacionando esse processo vivido por Ernesto ao que aponta Deleuze e Guattari (1997), na primeira parte deste artigo, o indivíduo é atravessado por sonoridades territoriais, essas sonoridades são marcações de territórios, "assinaturas" feitas com a intenção de definir espaços, já que o sino, "María Angola", representa a territorialidade estabelecida pela Companhia de Jesus. A religião desembarcou juntamente com o colonizador branco europeu, para catequizar os índios, salvar suas almas e levá-los ao paraíso. Mas, percebe-se também todo um imaginário construído em torno do sino, poderes mágicos de transformar objetos em ouro.

Outro espaço presente na narrativa usada por Arguedas para compreender a cidade de Cusco é a praça de armas. "Passamos a rua: cruzamos outra, muito larga, percorremos uma rua estreita. E vimos as cúpulas da catedral. Desembocamos na praça de Armas. Meu pai me levava pelo braço. Surgiram os portais brancos. Estávamos à sombra do templo" (ARGUEDAS, 2005, p. 15). A percepção de Ernesto está atenta a tudo que o cerca. Aos detalhes das paredes, do átrio e das construções de uma maneira geral.

Era maior de todas que eu já tinha visto. [...] Entramos na praça. As pequenas árvores plantadas no parque, e os arcos, pareciam intencionalmente apequenados, diante da catedral e das torres da igreja da Companhia.

[...] - Foi a praça de celebrações dos incas - disse meu pai. - olhe bem para ela, filho. Não é quadrada, mas longa de sul a norte. (ARGUEDAS, 2005, p. 15).

A representação da praça é importante para perceber a grandeza simbólica. $\mathrm{Na}$ verdade, ela já existia antes da chegada do colonizador, mas resistiu. Era usada para festejos e celebrações do imperador Inca. Com a chegada dos europeus e da Companhia de Jesus, ela se torna a praça da catedral. Há uma ressignificação, uma reterritorialização neste sentido. É em frente à praça de armas que está a opulenta catedral, como forma de sobreposição de uma cultura à outra. Mas, percebe-se que ainda conserva significados profundos com a cultura andina dos ancestrais incas. Vejamos:

- Papai - disse. - Quanto mais longe eu olho, mais alta me parece a catedral. Quem foi que fez?

- O espanhol, com a pedra inca e as mãos dos índios.

- A Companhia é mais alta.

- Não, é estreita. 


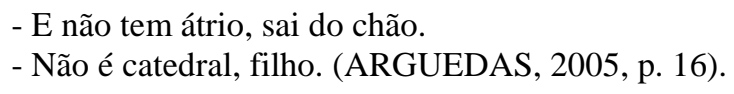

As construções do período colonial se tornam opulentas para demostrar grandeza e forçar a submissão. Porém, percebe-se que, no diálogo acima, o pai de Ernesto reforça uma identidade cultural forte, mesmo que de forma tímida, pois a catedral foi construída por ordem dos espanhóis, mas foram usadas as pedras incas e a mão de obra dos indígenas. Esse discurso reforça o conflito de identidade e deslocamento de territórios. As territorialidades vivem em constante movimento. Há um claro respeito dos personagens pela catedral e por tudo que ela representa. Mas também há um orgulho de serem descendentes dos povos originários que habitam a Cordilheira.

Deleuze e Guattari (1997) ampliam o conceito de território, pois, este, passa por um processo de força criadora. Criam-se territorialidades subjetivas articuladas com o desejo e o pensamento em ser, em pertencer. Qualquer objeto ou lugar pode ser um território, até uma música ou um livro. Levando em consideração o agenciamento maquínico das técnicas, dos corpos da natureza, que apresentam múltiplos movimentos que atravessam os corpos, as percepções e sentidos (HAESBAERT; BRUCE, 2002).

\begin{abstract}
Mesmo na penumbra se avistava o fio; a cal que unia cada pedra lavrada o ressaltava.

- Batendo nela com cinzéis tirariam seu "encanto". Mas as cúpulas das torres devem guardar, quem sabe, o esplendor que dizem existir na glória. Veja papai! Estão brilhando.

- Sim, filho. Você, por ser criança, vê algumas coisas que nós, os mais velhos, não enxergamos. A harmonia de Deus existe na Terra. Perdoemos o Velho, já que graças a ele você conheceu Cusco. Viremos à catedral amanhã. (ARGUEDAS, 2005, p. 17).
\end{abstract}

Pode-se considerar Ernesto como um sujeito heterogêneo, mestiço, híbrido, sendo aquele em cujo processo constitutivo participam e agem universos culturais distintos que o atravessam a todo momento. Sendo assim, o sujeito tende a identificar-se com os conteúdos simbólicos desses diferentes mundos, produzindo novas territorialidades e se desterritorializando e reterritorializando e, assim, sucessivamente. Ernesto vive em dois mundos distintos e antagônicos. Mundos rizomáticos.

Não é possível que seja de outra forma. A expressividade simbólica, o imaginário nesse sentido, parece brotar e se espalhar em diferentes direções. "Eu estava prevenido. Já vira Cusco. Sabia que por trás dos muros dos palácios incas viviam velhos avarentos. [...] A voz extensa do grande sino, os amarus $^{9}$ do palácio de Huayna Capac acompanhavamme, ainda. Estamos no centro do mundo.” (ARGUEDAS, 2005, p. 25). Esse momento é quando ele encontra o Velho pela primeira vez e este tenta intimidá-lo.

Ernesto reúne força e coragem ao evocar lembranças dos amarus, antigos deuses. Lembrou-se que estava na cidade de Cusco, capital do grande império inca, isso o fortalece. Percebe-se uma clareza de identidade, de sentimentos e de significados. Mesmo sendo atravessado por devires, ele sabe que sua cultura e dos seus ancestrais está enraizada naquele espaço urbano. É em Cusco que se fortalece sua identidade cultural.

Uma das estratégias de Arguedas, e que dão vigor a sua obra literária, é a utilização de elementos antagônicos e duais aos personagens. Esta dualidade se confunde a todo momento na narrativa. Se mesclam pensamentos, sentimentos, percepções, que revelam, aos poucos, a identidade heterogênea de Ernesto. As territorialidades são resignificadas constantemente.

\footnotetext{
${ }^{9}$ Segundo a mitologia indígena, Amaru era um deus em forma de serpente que habitava o fundo dos lagos e que foi transformado em touro.
} 
José María Arguedas, parece elaborar um projeto literário, pois toma para si essa tarefa de escrever sobre a realidade peruana, sobre a realidade de seu povo, sobre a história do povo andino. "Escrevemos por amor, prazer e necessidade, não por ofício. [...] Eu vivo para escrever, e creio que é preciso viver incondicionalmente para interpretar o caos e a ordem" (ARGUEDAS, 20016, p. 43). É nessa perspectiva que o autor usou toda sua originalidade, para interpretar o caos e a ordem. Dar uma espécie de sentido histórico, político e poético à narrativa literária foi, talvez, a sua grande tarefa. Ressalta-se que ele falava com propriedade de alguém que conheceu e viveu a realidade do mundo andino.

\section{CONSIDERAÇÕES FINAIS}

A tentativa de relacionar conceitos filosóficos a uma obra literária é, na verdade, uma forma de buscar outros caminhos que possam enriquecer a leitura e análise de uma obra de arte. Neste sentido, o diálogo estabelecido no artigo é de ir em direção a novos territórios e construir territorialidades múltiplas que se cruzam a partir do romance ficcional. Utilizar os conceitos deleuzeguattarianos e aplicá-los em novas possibilidades de leituras da narrativa ficcional. Como se vê no livro Os rios profundos (1958/2005), existe um narradorpersonagem que é constantemente atravessado e deslocado, isso o faz movimentar-se num terreno heterogêneo e plural. Ernesto reflexiona sobre o papel que a cultura incaica exerce na cidade de Cusco e nele próprio. Mesmo sendo uma cidade com marcas da modernidade, ainda guarda muitos elementos simbólicos que ajudam a construir identidades, mesmo que sejam, identidades plurais, hibridas e heterogêneas.

O espaço urbano de Cusco favorece um movimento rizomático das territorialidades, pois é nesse espaço ficcional que se encontram imbricados os diversos mundos antagônicos. Modernidade; tradição; Estado; cultura popular; cultura erudita; religião; religiosidade; imaginário; múltiplas linguagens. É nesse espaço que Ernesto, a partir de suas experiências subjetivas, constrói suas identidades que, muitas vezes, entram em conflito, mas que dão suporte para entender toda a realidade que o cerca.

Importante ressaltar que a intelectualidade peruana, na época de José María Arguedas, discutia qual o papel que o índio iria assumir na suposta sociedade moderna que se formava. Como pesquisador, escritor e intelectual que Arguedas era, ele começa pela literatura a apontar uma direção. Sabe-se que tal estratégia não foi unânime. Na verdade, há uma tentativa de desqualificar o trabalho literário de Arguedas, por parte de alguns escritores. Mas que não encontrou eco na crítica literária, pois o conjunto da obra arguediana é considerada pela crítica especializada algo consistente e de uma qualidade inquestionável.

Conforme visto, José María Arguedas assume um projeto de escritura literária que não é puramente descritivo, mas faz uma reflexão e mostra uma realidade. Enquanto escritor, Arguedas usa sua originalidade para inserir o indígena como ele realmente é. Um índio com cultura, formas de vida, cosmovisão e identidade. Por isso ele é considerado como o impulsionador da corrente neo-indigenista no Peru e na América Latina.

A partir dessa perspectiva, pretende-se esclarecer que não é o objetivo fazer análises fechadas, com verdades absolutas. Verifica-se que no texto literário, a partir do escritor Arguedas, passando pelo narrador-personagem Ernesto, ambos possuem territorialidades que dialogam a todo momento. Os diversos territórios contidos no romance ajudam a compreender melhor a dinâmica escritural de Arguedas e ajudam a estabelecer um diálogo com outras áreas do saber. Um diálogo para entender a riqueza dos conceitos filosóficos com a obra de arte literária, algo que não se esgota em si mesmo. 


\section{REFERÊNCIAS}

ARGUEDAS, José Maria. A raposa de cima e a raposa de baixo. Tradução de Rômulo Monte Alto. Belo Horizonte: Editora UFMG, 2016.

ARGUEDAS, José Maria. Os rios profundos. Tradução de Josely Vianna Baptista. São Paulo: Companhia das Letras, 2005.

BERMAN, Marshall. Tudo que é sólido desmancha no ar: a aventura da modernidade. São Paulo: Companhia das Letras, 2007.

CASTRO, Ana Claudia Veiga de. Figurações da cidade: um olhar para a literatura como fonte da história urbana. In.: Revista Anais do Museu Paulista: História e Cultura Material. São Paulo, v.24, n.3, p.99-120, dez. 2016. Disponível em: http://www.revistas.usp.br/anaismp/article/view/126844. Acesso: em 10 ago. de 2020.

CHELOTTI, Marcelo Cervo. Reterritorialização e identidade territorial. In.: Revista Sociedade \& Natureza, Uberlândia, 22 (1):165-180, abr. 2010. Disponível em: http://www.seer.ufu.br/index.php/sociedadenatureza/issue/view/548. Acesso em: 12 de ago. de 2020.

CORNEJO POLAR, Antonio. Escribir en el aire: ensayo sobre la heterogeneidad sociocultural en las literaturas andinas. Lima-Peru: Editorial Horizonte, 1994.

DELEUZE, Gilles; GUATTARI, Félix. Acerca do ritornelo. In.: DELEUZE, Gilles; GUATTARI, Félix. Mil Platôs, v.4. Trad. Suely Rolnik. São Paulo: Editora 34, 1997.

DELEUZE, Gilles; GUATTARI, Félix. O que é a filosofia? Trad. Adolfo Muñoz. São Paulo: Editora 34, 1992.

DELEUZE, Gilles; GUATTARI, Félix. Rizoma. In.: DELEUZE, Gilles; GUATTARI, Félix. Mil Platôs, v.1. Trad. Aurélio Guerra Neto e Celia Pinto Costa. São Paulo: Editora 34, 1995.

GRANETTO MOREIRA, Julia Cristina; DAL MOLIN, Beatriz Helena. Território e Desterritorialização: A EaD na Universidade Estadual do Oeste do Paraná. In.: Revista EAD em Foco, Rio de Janeiro, v.9 n.1, 2019. Volume único. Disponível em: https://eademfoco.cecierj.edu.br/index.php/Revista/article/view/775. Acesso em: $10 \mathrm{de}$ ago. de 2020.

HAESBAERT, Rogério; BRUCE, Glauco. A desterritorialização na obra de Deleuze e Guattari. In.: Revista GEOgraphia, Niterói, ano IV, n.7, p.7-31, 2002. Disponível em: https://periodicos.uff.br/geographia/article/view/13419. Acesso em 12 de ago. de 2020.

HAESBAERT, Rogério. Identidades territoriais. In.: ROSENDAHL, Zeny; CORREAA, Roberto L. Manifestações da cultura no espaço. Rio de Janeiro: Eduerj, 1999.

KAUSS, Vera Lúcia Teixeira; LIMA, Jaqueline de Cássia Pinheiro. Cusco: a dessacralização da cidade imperial dos incas no romance de José Maria Arguedas. In.: Revista Espaço Acadêmico, Maringá (UEM), v. 156, p. 154-163, 2014. Disponível em: 
http://periodicos.uem.br/ojs/index.php/EspacoAcademico/article/view/23069. Acesso em: 05 de ago. de 2020.

MOISÉS, Massaud. História da literatura brasileira contemporânea: Modernismo. São Paulo: Cultrix, 2001.

PORTUGAL, Ana Raquel. Mitos e fatos nas crônicas da conquista do Antigo Peru. In.: Revista História Unisinos, São Leopoldo, 14(2):112-120, Maio/Agosto 2010. Disponível em: http://revistas.unisinos.br/index.php/historia/article/view/4712. Acesso em: $13 \mathrm{de}$ ago. de 2020. 